\title{
Epidemiological characteristics of premature infants born at General Hospital Pula in a five-year-period (2012-2016)
}

\section{Epidemiološke karakteristike nedonoščadi rođene u Općoj bolnici Pula u petogodišnjem razdoblju (2012. - 2016.)}

\author{
Mladen Jašić ${ }^{1 *}$, Dorotea Drašković 2 , Ivona Butorac Ahel ${ }^{3}$, Darko Kraguljac ${ }^{4}$
}

\begin{abstract}
Aim: To summarize our five-year experience in management of premature infants at our second level neonatal facility. Patients and methods: This prospective birth cohort study was performed at the Division of Neonatology (level 2), Department of Paediatrics, General hospital Pula during a five-year-period (January $1^{\text {st }} 2012$ - December $31^{\text {st }} 2016$ ). The study population included all live-born neonates born between $22^{\text {nd }}$ and $37^{\text {th }}$ gestational week. Results: During the above mentioned five-year-period, 289 premature infants were born at General Hospital Pula. One-hundred and sixty seven (58\%) neonates were delivered vaginally and $122(42 \%)$ were delivered by caesarean section. Nineteen $(7 \%)$ neonates were born after in vitro fertilization. Infants were mostly male ( $\mathrm{N}=167 ; 58 \%)$, and appropriate for gestational age $(\mathrm{N}=240 ; 83 \%)$. Also, the infants belonged mostly to the late-preterm group $(\mathrm{N}=245 ; 85 \%)$. Thirty-three premature infants $(11 \%)$ were transferred to a tertiary paediatric centre and five neonates died (2\%). The overall cost of hospital stay for hospitalized premature infants was 2,517,000 Croatian kunas (cost for one patient: median 4800, range $3,225-53,325$ ); in euros, it was 335,600 (cost for one patient: median 640, range 430-7,110) respectively. The overall hospital stay was $10.01 \pm 8.30$ days (median 8.00 , range 1.00-67.00). Conclusion: Despite the great development of neonatal intensive care, the best prevention of complications related to prematurity is to prevent preterm labour.
\end{abstract}

Key words: epidemiology; morbidity; mortality; premature infant
${ }^{1}$ Department of Physical therapy, Orthopaedic and Rehabilitation Hospital "Martin Horvat", Rovinj, Croatia

${ }^{2}$ Department of Paediatrics, General Hospital Pula, Pula, Croatia

${ }^{3}$ Department of Paediatrics, Clinical Hospital Centre Rijeka, Rijeka, Croatia

${ }^{4}$ Department of Physical therapy, Orthopaedic and Rehabilitation Hospital "Martin Horvat", Rovinj, Croatia

\begin{abstract}
Sažetak. Cilj: Prikazati kliničko-patološke karakteristike nedonoščadi liječene u našoj ustanovi u petogodišnjem razdoblju. Ispitanici i metode: Ova prospektivna studija učinjena je u Jedinici za bolesnu novorođenčad Odjela za pedijatriju Opće bolnice Pula (2. razina neonatalne skrbi) u petogodišnjem razdoblju (1. siječnja 2012. - 31. prosinca 2016.). U ispitivanje je uključena sva nedonoščad rođena između 22. i 37. navršenog tjedna trudnoće. Rezultati: Tijekom navedenog petogodišnjeg razdoblja u Općoj bolnici Pula rođeno je dvjesto osamdeset i devetero nedonoščadi. Stotinu šezdeset i sedmero ( $58 \%$ ) nedonoščadi rođeno je vaginalnim putem, a stotinu dvadeset i dvoje (42\%) carskim rezom. Devetnaestero (7\%) novorođenčadi rođeno je nakon postupka umjetne oplodnje. Nedonoščad je bila većinom muškog spola ( $\mathrm{N}=167 ; 58 \%$ ) i normalne mase u odnosu na gestacijsku dob ( $\mathrm{N}=240 ; 83 \%)$. Najviše je nedonoščadi bilo u skupini kasne nedonoščadi ( $N=245 ; 85 \%)$. Trideset i troje nedonoščadi $(11 \%)$ premješteno je u tercijarni pedijatrijski centar, a petero je nedonoščadi preminulo (2\%). Ukupna cijena liječenja nedonoščadi bila je $2.517 .000,00$ kuna (prosječna cijena boravka jednog nedonoščeta: medijan 4800, raspon 3225 - 53.325) ili 335.600 eura (prosječna cijena boravka jednog nedonoščeta: medijan 640, raspon 430 - 7110). Prosječno

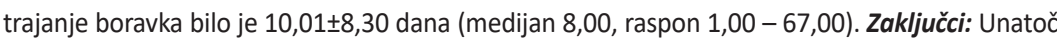
velikom napretku u neonatalnoj skrbi i boljim mogućnostima njege/liječenja nedonoščeta, najbolja prevencija komplikacija prematuriteta ostaje i dalje prevencija prijevremenog poroda.
\end{abstract}

Ključne riječi: epidemiologija; morbiditet; mortalitet; nedonošče

\author{
"Corresponding author: \\ Mladen Jašić, M.D., Ph.D. \\ Department of Physical therapy, \\ Orthopaedic and Rehabilitation Hospital \\ "Martin Horvat", Rovinj, Croatia \\ Luigi Monti 2, Rovinj \\ E-mail:mladen.jasic@gmail.com
}

http://hrcak.srce.hr/medicina 


\section{INTRODUCTION}

Infants born before the $37^{\text {th }}$ gestational week (GW) are premature infants. Based on gestational age, premature infants can further be subdivided in three categories: moderate to late preterm (32 to $37 \mathrm{GW}$ ), very preterm ( 28 to $32 \mathrm{GW}$ ) and extremely preterm $(<28 \mathrm{GW})^{1}$.

Every year about 15 million babies are born preterm, and the number is still rising, affecting families and health systems all over the world ${ }^{1}$.

The aim of this article was to present the epidemiological characteristics of premature infants born in a secondlevel neonatal care facility (such as General Hospital Pula) so that a young and inexperienced physician or a young and inexperienced nurse can learn and understand what to expect in a job at that institution in a five-yearperiod.

Despite great advances in perinatal/neonatal care, prematurity still remains a major cause of overall neonatal morbidity and mortality ${ }^{2}$. It is estimated that one million children die each year due to complications of preterm birth ${ }^{3,4}$. The majority of preterm births spontaneously happen and the exact causes remain unknown. Some factors like infections, multiple pregnancies, diabetes, hypertension, etc. are known to be the possible causes of preterm birth ${ }^{1}$. Prematurity is the leading cause of newborn deaths and is nowadays the second leading cause of death, after pneumonia, in children under the age of 5 years ${ }^{3}$. Health problems that can affect premature infants include apnoea, respiratory distress syndrome (RDS), intraventricular haemorrhage (IVH), periventricular leukomalacia (PVL), patent ductus arteriosus (PDA), necrotizing enterocolitis (NEC), retinopathy of prematurity (ROP), jaundice, anaemia, bronchopulmonary dysplasia (BPD) and infections ${ }^{5}$. In high-income countries, improved care of the premature baby is a result of the development of Neonatal Intensive Care Units (NICU). In 2007, the Institute of medicine reported that in 2005 the annual societal economic cost associated with preterm birth (medical, educational and lost productivity combined) was at least $\$ 26.2$ billion. During the same year, the first-year medical costs were about 10 times greater for preterm than for term infants and the average length of hospital-stay was nine times longer for a premature infant (1.5 vs. 13 days) ${ }^{2}$.

In Croatia, hospitals that provide care for newborn infants are classified on the basis of functional capabilities and are organized within a regionalized system of perinatal care as seen in western countries ${ }^{6}$. Level I hospitals provide basic neonatal care for healthy newborn infants. Also, personnel are trained to perform neonatal resuscitation and stabilization of ill neonates until transfer to a Neonatal Intensive Care Unit (NICU). Level II nurseries can provide care to a moderately ill neonates and premature infants and can provide care to neonates recovering from serious illness treated in Level III facility (NICU). The weight and GW cut-off for a second level facility is not straight, and most level II hospitals can provide care to infants born after $32^{\text {nd }}-34^{\text {th }} \mathrm{GW}$ and infants weighing more than $1500-1800 \mathrm{~g}$. Regional neonatal centres with NICU and neonatal surgery are present in Zagreb, Osijek, Rijeka and Split. Neonatal transfer from a lower to higher level of neonatal care (NICU) in Croatia is performed by a medical team of a lower level facility, and in developed countries the transport of a critically ill neonate is performed by specialized medical team from tertiary centre that is coming to get the ill neonate. Neonatology division at General hospital Pula is a second level neonatal facility and treat infants born $\geq 32^{\text {nd }} \mathrm{GW}$ and with a birth weight $\geq 1500 \mathrm{~g}$. Infants born before the $32^{\text {nd }} \mathrm{GW}$ or with a birth weight less than 1500 grams or those necessitating longer respiratory support, specific clinical diagnostics or surgical treatment are transported to a tertiary paediatric centre mostly to Clinical Hospital Centre Rijeka7. The aim of our article is to summarize our fiveyear experience in management of premature infants at our second level neonatal facility in a five-year-period.

\section{PATIENTS AND METHODS}

This prospective birth cohort study was performed at the Division of Neonatology (level 2), Department of Paediatrics, General hospital Pula 
during a five-year-period (January $1^{\text {st }} 2012$ - December $31^{\text {st }}$ 2016). The study population included all live-born neonates born between $22^{\text {nd }}$ and $37^{\text {th }} \mathrm{GW}$. Gestational age was calculated based on the first day of the last menstrual period (LMP). In cases where LMP was not known, gestational age was assessed using obstetric ultrasonography. The birth weight was measured using an electronic scale with a sensitivity of 10 grams. Birth length and birth head circumference are reported in centimetres. The Apgar scores were calculated in delivery room by an experienced neonatologist. The measured outcomes were cardiopulmonary resuscitation (CPR), intubation and mechanical ventilation (MV), umbilical vein catheterisation, surfactant therapy, respiratory support with nasal continuous positive airway pressure (nCPAP), antibiotic therapy, infusion therapy, oxygen therapy, respiratory distress syndrome (RDS), perinatal infection, hypoglycaemia, hyponatremia, hypocalcaemia, jaundice, intraventricular haemorrhage (IVH), patent ductus arteriosus (PDA), retinopathy of prematurity (ROP), neonatal transport to a Tertiary centre and mortality.

\section{Statistical analysis}

Numerical variables were presented as mean $\pm S D$, median and $5^{\text {th }}$ and $95^{\text {th }}$ percentiles or median and range. Categorical variables were presented as frequencies and percentages and analysed using Pearson's chi-square and Fisher's exact tests. Statistical significance was determined as $p$ value $<0.05$.

\section{RESULTS}

During the above mentioned five-year-period, 289 premature infants were born at General Hospital Pula. One-hundred and sixty seven (58\%) neonates were delivered vaginally and 122 (42\%) were delivered by caesarean section. Nineteen (7\%) neonates were born after in vitro fertilization. The demographic characteristics of premature infants are summarized in Table 1 . Infants were mostly male ( $\mathrm{N}=167 ; 58 \%)$, and appropriate for gestational age (AGA) ( $N=240 ; 83 \%)$. Also, the infants belong mostly to the late-preterm group $(\mathrm{N}=245 ; 85 \%)$. The numbers of all live born ne-
Table 1. Demographic characteristics of premature infants

\begin{tabular}{|c|c|}
\hline $\begin{array}{l}\text { Demographic characteristics of } \\
\qquad(\mathrm{N}=\mathbf{2 8 9})\end{array}$ & emature infants \\
\hline Sex & \\
\hline Male & $167(58)$ \\
\hline Female & $122(42)$ \\
\hline Gestation (weeks) & \\
\hline 23 & $1(0.3)$ \\
\hline 24 & $2(0.7)$ \\
\hline 25 & $0(0.0)$ \\
\hline 26 & $0(0.0)$ \\
\hline 27 & $5(1.7)$ \\
\hline 28 & $0(0.0)$ \\
\hline 29 & $1(0.3)$ \\
\hline 30 & $1(0.3)$ \\
\hline 31 & $6(2.1)$ \\
\hline 32 & $6(2.1)$ \\
\hline 33 & $22(7.6)$ \\
\hline 34 & $58(20.1)$ \\
\hline 35 & $70(24.2)$ \\
\hline 36 & $117(40.5)$ \\
\hline Birth weight (g)* & $\begin{array}{c}2460(1474- \\
3362)\end{array}$ \\
\hline $\begin{array}{l}\text { SGA } \\
\text { AGA }\end{array}$ & $\begin{array}{l}3362) \\
41(14)\end{array}$ \\
\hline $\begin{array}{l}\text { AGA } \\
\text { LGA }\end{array}$ & $240(83)$ \\
\hline & $8(3)$ \\
\hline Birth length $(\mathrm{cm})^{*}$ & $46.0(39.5-50.0)$ \\
\hline Birth head circumference $(\mathrm{cm})^{*}$ & $32.5(29.0-35.6)$ \\
\hline $\begin{array}{l}\text { Data are presented as median }\left(5^{\text {th }}-95\right. \\
\text { frequencies (percentages). Frequencie } \\
\text { marked with "*". SGA: small for gestati } \\
\text { AGA: appropriate for gestational age; } \\
\text { gestational age. }\end{array}$ & $\begin{array}{l}\text { ercentiles) or } \\
\text { ercentages) are } \\
\text { al age; } \\
\text { : large for }\end{array}$ \\
\hline
\end{tabular}

onates and premature infants born at our hospital are presented in Table 2. The outcomes of premature infants are summarized in Table 3 . The overall cost of hospital stay for hospitalized premature infants was 2,517,000 Croatian kunas (cost for one patient: median 4800, range 3,225$53,325)$; in Euros, it was 335,600 (cost for one patient: median 640 , range $430-7,110$ ) respectively. The overall hospital stay was $10.01 \pm 8.30$ days (median 8.00, range 1.00-67.00). Thirty-three premature infants $(11 \%)$ were transferred to a Tertiary paediatric centre and five neonates died (1.7\%). 
Table 2. Number of all live born infants and number of all preterm infants born at General hospital Pula in a five-year-period

\begin{tabular}{|c|c|c|}
\hline Year & All infants & $\begin{array}{c}\text { Premature infants } \\
\text { N (\%) }\end{array}$ \\
\hline $\mathbf{2 0 1 2}$ & $\mathbf{N}$ & $62(4.6)$ \\
\hline $\mathbf{2 0 1 3}$ & 1323 & $40(3.0)$ \\
\hline $\mathbf{2 0 1 4}$ & 1325 & $66(4.7)$ \\
\hline $\mathbf{2 0 1 5}$ & 1397 & $56(4.3)$ \\
\hline $\mathbf{2 0 1 6}$ & 1300 & $65(4.9)$ \\
\hline & 1330 & $289(4.3)$ \\
\hline
\end{tabular}

Table 3. Outcomes of premature infants

\begin{tabular}{|l|r|r|r|}
\hline \multicolumn{1}{|c|}{ Therapy } & Yes & No & $\boldsymbol{p}$ value \\
\hline CPR & 14 & 275 & $<0.0001$ \\
\hline Intubation and MV & 64 & 225 & $<0.0001$ \\
\hline $\begin{array}{l}\text { Umbilical vein } \\
\text { catheterisation }\end{array}$ & 15 & 274 & $<0.0001$ \\
\hline Surfactant therapy & 61 & 228 & $<0.0001$ \\
\hline Antibiotic therapy & 123 & 166 & 0.01 \\
\hline Infusion therapy & 262 & 27 & $<0.0001$ \\
\hline Oxygen therapy & 259 & 30 & $<0.0001$ \\
\hline RDS & 65 & 223 & $<0.0001$ \\
\hline Perinatal infection & 64 & 224 & $<0.0001$ \\
\hline Hypoglycaemia & 62 & 226 & $<0.0001$ \\
\hline Hyponatremia & 21 & 267 & $<0.0001$ \\
\hline Hypocalcemia & 24 & 264 & $<0.0001$ \\
\hline Jaundice & 175 & 113 & 0.0003 \\
\hline IVH & 9 & 280 & $<0.0001$ \\
\hline PDA & 10 & 279 & $<0.0001$ \\
\hline
\end{tabular}

Data are presented as frequencies. CPR: cardiopulmonary resuscitation; MV: mechanical ventilation; nCPAP: nasal continuous positive airway pressure; IVH: intraventricular haemorrhage; PDA: patent ductus arteriosus; ROP: retinopathy of prematurity. vant and available Croatian literature ${ }^{12-14}$. Our results showed that more than half of preterm neonates were delivered vaginally, they were mostly male and they're weight were mostly appropriate for gestational age which is similar to data found in the literature ${ }^{2,3}$.

On an annual basis, the percentage of preterm infants in our study was between 3 and $5 \%$ which is much less than the percentage found in the literature $^{1-3}$. WHO estimated that the global preterm birth rate is about $11.1 \% \%^{1-3}$. Globally, rates are highest on average for low-income countries (11.8\%), followed by lower middle-income countries $(11.3 \%)$ and lowest for upper middle- and high-income countries $(9.4 \% \text { and } 9.3 \%)^{3}$. It is necessary to emphasize that more than $60 \%$ of all preterm births occur in sub-Saharan Africa and South Asia $(12.8 \%)^{1-3}$. A small number of premature deliveries in our hospital is probably a result of a very good prenatal and perinatal care at both Primary and Secondary levels of Gynaecologic and Obstetric care in Istria County. Preterm infants born before $32^{\text {nd }} \mathrm{GW}$ often require specialised care in Tertiary neonatal centre and therefore, it is necessary, if the time permits, to transport a pregnant woman with high risk of delivery before the $32^{\text {nd }} \mathrm{GW}$ to a Tertiary centre since in utero transfer has better clinical outcome for mother and infant than transfer after birth ${ }^{15}$. In our study, about $1 \%$ of all pregnant women with a high risk of a birth before the $32^{\text {nd }} \mathrm{GW}$ were transported in a Tertiary neonatal centre before the delivery. In comparison to similar study where about $11 \%$ of pregnancies were transported in utero we had significantly lower percentage of in utero transfer ${ }^{16}$.

The most frequent therapeutic interventions in our premature infants were oxygen and intravenous fluid administration. Broad spectrum antibiotic therapy covering group B Streptococcus, Escherichia coli and Listeria monocytogenes was given in only $43 \%$ of cases; only neonates who had a high risk of developing early onset sepsis and neonates with a severe respiratory distress received antibiotic therapy while stabile neonates did not receive antibiotics but were frequently evaluated (clinically and using laboratory tests). At our facility, antibiotics have been used wisely, since their administration may alter the diversity of the intestinal microbiome resulting in 
overgrowth of pathogenic bacteria, for example Enterobacter spp which can further lead to NEC ${ }^{17}$. Other undertaken treatments included exogenous surfactant and nCPAP respiratory support. At our facility exogenous surfactant has been given by INSURE method (Intubation, Surfactant administration and Extubation) which is followed by nCPAP (nasal Continuous Positive Airway Pressure). Premature infants whose condition did not improve despite surfactant administration and nCPAP respiratory support were intubated, placed on mechanical ventilation and transferred to a Tertiary centre $(\mathrm{N}=33.11 \%)$. The rates of transport to a Tertiary centre and overall mortality are significantly less than in similar studies ${ }^{11,16}$. Hypoglycaemia, hypocalcaemia and hyponatraemia were found in $62(22 \%), 24(8 \%)$ and $21(7 \%)$ cases respectively. According to the literature, nearly $30-60 \%$ of preterm neonates, small for gestational age and intrauterine growth restricted neonates develop hypoglycaemia due to their lack of metabolic reserves and associated comorbidities $^{18}$. Approximately one-third of preterm infants and most of the very low birth-weight infants have low serum calcium levels during the first 48 hours of life ${ }^{19}$. Premature infants are at high risk for the development of hyponatremia because of (1) lower glomerular filtration rate, (2) reduced proximal tubular reabsorption of sodium, and (3) increased arginine vasopressin levels in response to illness ${ }^{20}$. The results from the retrospective cohort analysis of 126 preterm infants born before $36 \mathrm{GW}$ showed that $29.4 \%$ of infants enrolled in the study had hyponatremi $a^{20}$. Since the incidence of electrolyte imbalances is inversely proportional to gestational age, the difference between our results and the results found in the literature could be explained by the fact that we had only a small number of moderately, very and extremely preterm neonates (15\%); our neonates belonged mostly to late preterm group ( $\mathrm{N}=245 ; 85 \%)$. RDS was present in $23 \%$ of cases, perinatal infection in $23 \%$ of cases, IVH and PDA were present in $3 \%$ of cases, ROP was diagnosed in $1 \%$ of neonates. These results are similar to those found in the literature $e^{9-14}$.

\section{CONCLUSIONS}

More than a half of preterm neonates were delivered vaginally, they were mostly male and had birth-weight appropriate for gestational age. Also, the majority of neonates belonged to late preterm group (85\%). We emphasize the necessity of wise use of broad-spectrum antibiotics, they should be given only in preterm neonates with high risk for development of serious bacterial infection and sepsis or neonates with severe respiratory distress. Also, we recommend the use of INSURE method for surfactant application followed by non-invasive respiratory support (nCPAP) to minimize the need for mechanical ventilation and the rate of transfer to a Tertiary centre.

In the past thirty years, there have been great advances in perinatal and neonatal care which resulted in better survival of premature infants, even the extremely premature ones, but since premature birth is related to great morbidity the prevention of premature birth remains still the best measure for prevention of neonatal complications following premature birth.

Premature birth is the leading cause of neonatal mortality and morbidity and it is still one of the biggest problems of modern perinatology. Despite great development of neonatal intensive care, the best prevention of complications related to prematurity remains the prevention of preterm delivery. Studies like this can increase the knowledge and competency of a young and inexperienced physicians and nurses and help them in their work at Secondary neonatal facility.

Conflicts of interest: Authors declare no conflicts of interest.

\section{REFERENCES}

1. World Health Organization. WHO recommendations on interventions to improve preterm birth outcomes. Geneva, Switzerland, 2015.

2. Blencowe $H$, Cousens S, Chou D, Oestergaard M, Say L, Moller AB et al. Born Too Soon: The global epidemiology of 15 million preterm births. Reprod Health 2013;10:S2.

3. Howson CP, Kinney MV, McDougall L, Lawn JE; Born Too Soon Preterm Birth Action Group. Born too soon: preterm birth matters. Reprod Health 2013;10:S1.

4. Liu L, Oza S, Hogan D, Chu Y, Perin J, Zhu J et al. Global, regional, and national causes of under-5 mortality in 2000-15: an updated systematic analysis with implica- 
tions for the Sustainable Development Goals. Lancet 2016;388:3027-35.

5. Jašić M, Štifter S, Sindičić Dessardo N, Rukavina KM, Mustać E, Belci D. The relationship between histologic chorioamnionitis and decidual macrophage polarization and their influence on outcomes of neonates born before the $32^{\text {nd }}$ gestational week. J Matern Fetal Neonatal Med 2019;8:1-10.

6. Committee on Fetus and Newborn. Levels of Neonatal Care. Pediatrics 2004;114:1341-7.

7. Jašić $M$, Becker M, Milevoj Ražem M, Jotanović Ž. Epidemiologic characteristics of neonates transferred from General Hospital Pula to a tertiary pediatric center in a 10-year-period (2006-2015). Glasnik Pulske Bolnice 2017; Vol XII/1:14-6.

8. Ndelema B, Van den Bergh R, Manzi M, van den Boogaard W, Kosgei RJ, Zuniga I et al. Low-tech, high impact: care for premature neonates in a district hospital in Burundi. A way forward to decrease neonatal mortality. BMC ResNotes 2016;9:28.

9. Carriere D, Kantor E, Torchin H, Le Ray C, Jarreau PH, Zana-Taieb E. Mortality and morbidity of preterm neonates weighing less than 750g: A 2-year retrospective cohort study. Arch Pediatr 2020;27:227-32.

10. Raghuveer TS, Zackula R. Strategies to Prevent Severe Retinopathy of Prematurity: A 2020 Update and Metaanalysis. Neoreviews 2020;21:e249-e263.

11. Myrhaug HT, Brurberg KG, Hov L, Markestad T. Survival and Impairment of Extremely Premature Infants: A Meta-Analysis. Pediatrics 2019;143:e20180933.
12. Filipović-Grčić B, Rodin U, Ninković D, Stipanović J, Grizelj R, Stipanović JG et al. Smrtnost novorođenčadi do otpusta iz bolnice u Republici Hrvatskoj u 2016. godini. Gynecol Perinatol 2017;26(Suppl 1):26-36.

13. Filipović-Grčić $B$, Rodin U, Runtić $B$, Bakoš $M$, Čančarević G, Ninković D. Smrtnost novorođenčadi do otpusta iz bolnice u Republici Hrvatskoj u 2015. Godini. Gynaecol Perinatol 2016;25(Suppl 2):26-36.

14. Filipović-Grčić B, Mustapić Ž, Rodin U, Bartoniček D, Grizelj R. Smrtnost novorođenčadi do otpusta iz bolnice u Republici Hrvatskoj u 2014. godini. Gynecol Perinatol 2015;24(Suppl 1):26-32.

15. Fowlie PW, Booth $\mathrm{P}$, Skeoch $\mathrm{CH}$. Moving the preterm infant. BMJ 2004;329:904-6.

16. Griss CP, Tracy SK, Tracy M, Monk A: Transfer from primary maternity unit to tertiary hospital in New Zealand - timing, frequency. Midwifery 2015;879-87.

17. Cotten CM. Adverse Consequences of Neonatal Antibiotic Exposure. Curr Opin Pediatr 2016;28:141-9.

18. Sharma A, Davis A, Shekhawat PS. Hypoglicaemia in the preterm neonate: etiopathogenesis, diagnosis, management and long-term outcomes. Transl Pediatr 2017;6: 335-48.

19. Vuralli D. Clinical Approach to Hypocalcemia in Newborn Period and Infancy: Who Should be Treated? Int J Pediatr 2019;2019:4318075.

20. Hao TK. Prevalence and Risk Factors for Hyponatremia in Preterm Infants. Open Access Maced J Med Sci 2019;7: 3201-4. 